Afr. J. Trad. CAM (2005) 2 (3): 282 - 301

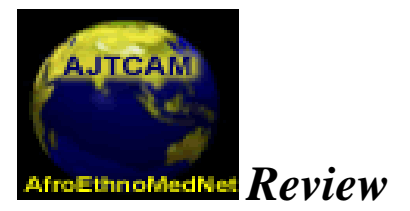

ISSN 0189-6016@2005
Afr. J. Traditional, Complementary and Alternative Medicines www.africanethnomedicines.net

\title{
THE NIGERIAN ZANTHOXYLUM; CHEMICAL AND BIOLOGICAL VALUES
}

\author{
S. K. Adesina \\ Drug Research \& Production Unit, Faculty of Pharmacy, \\ Obafemi Awolowo University, Ile-Ife, Nigeria. \\ E-mail: sadesina@oauife.edu.ng
}

\section{Abstract}

The Nigerian Zanthoxylum is a common component of the rain forest vegetation of Southern Nigeria, and is represented by eleven species. A few of these species occur more abundantly in the savannah and dry forest vegetation of South-western Nigeria. The eleven Zanthoxylum species demonstrate very close similarities and relationships among themselves, and are identified as trees, erect shrubs or small trees, straggling or scandent shrubs or as a forest liane. Traditional healers throughout Nigeria have used species of the Zanthoxylum for the treatment of a wide range of disorders, including toothache, urinary and venereal diseases, rheumatism and lumbago. Metabolites isolated from Zanthoxylum species so far include alkaloids, aliphatic and aromatic amides, lignans, coumarins, sterols, carbohydrate residues etc. Some of the metabolites have shown cytotoxic, molluscicidal, anticonvulsant, antisickling, anaesthetic, antibacterial, anti-hypertensive and anti-inflammatory properties. A common feature of most, if not all, the species studied is the wonderful capacity to produce gums and volatile oils. These vary in composition and so show different properties.

In this presentation, the author has discussed the chemistry of the various species examined to date. The focus has been on the local uses and commercial importance of the species, the values of the various metabolites in medicine and their general potential in drug development.

Key words: Nigerian Zanthoxylum, Medicinal plants, Medicinal values, Drug development

\section{Introduction}

Many developing countries of the world are endowed with vast resources of natural products. This priceless heritage which includes medicinal plants, have been used by indigenes for centuries as drug substances for relief from illnesses, as health-care products, fragrances, flavours, sweeteners and as materials for pest-control. And today, plants appear to be the almost exclusive source of drugs for the majority of the world's population, with 
Afr. J. Trad. CAM (2005) 2 (3): 282 - 301

substances derived from higher plants constituting about a quarter of all prescribed medicines (Principe, 1989). Such drugs derived from natural products include: (1) purgative drugs, usually a mixture of anthraquinone derivatives from Cassia or related species. (2) anti-ulcer drugs, carbenoxolone from Glycyrrhiza glabra roots; also Pulvia Bismuth Compositus BP which is a mixture of bismuth carbonate, magnesium carbonate and sodium carbonate and (3) the antihepatotoxic drug, Legalon which contains in part, the flavononol lignans, silymarin form Silybum marianum L. Gaertn. Others include (4) the antimalarial drug, quinine from Cinchona bark, and (5) emetine from the root of Ipecacuanha to mention but a few.

Of great concern, however, is the fact that many of these natural products are exported (Pousset, 1988) to developed countries as raw materials for their industries overseas. The refined products, that is, the valued-added products are then imported back and these usually cost many times more than the original benefits derived from exporting the raw materials. African countries export so much of their natural products to pharmaceutical industries overseas annually maybe for want of a quick monetary reward or for lack of know-how or trained man-power to develop them locally. The implications are that the actual values of these natural products are not retained in the countries of origin.

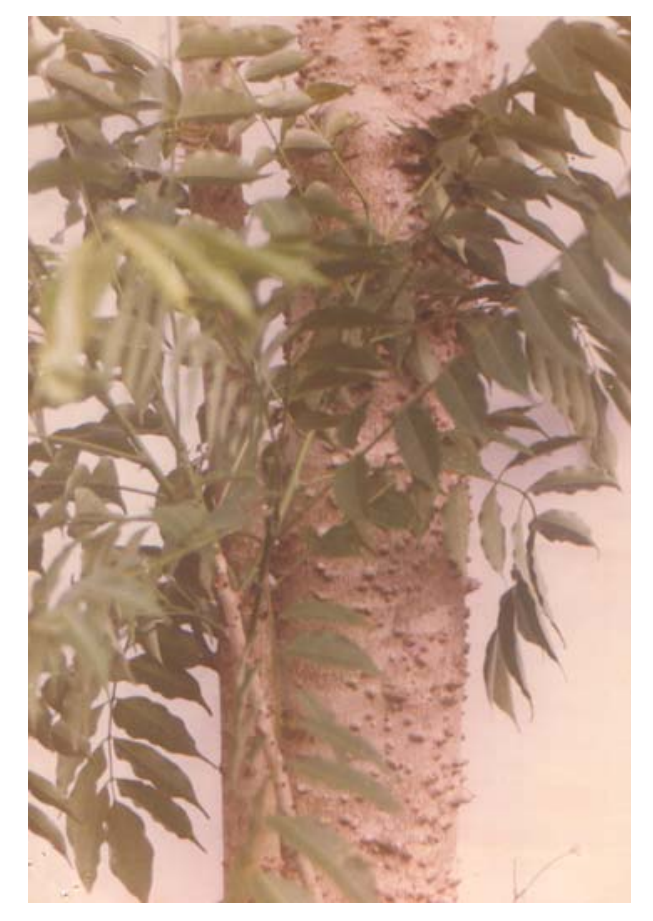

Figure 1: Zanthozylum rubescens growing in the wild

The genus Zanthoxylum Linn (Rutaceae) is represented (Olatunji, 1983) in Nigeria by eleven distinct species (Table 1). 
Afr. J. Trad. CAM (2005) 2 (3): 282 - 301

\section{Table 1: $\quad$ Zanthoxylum species identified in Nigeria}

\begin{tabular}{|l|l|}
\hline No & Names \\
\hline 1. & Zanthoxylum bouetense (Pierre ex. Letouzey) Waterm. \\
2. & Zanthoxylum buesgenii (Engl.) Waterm. \\
3. & Zanthoxylum dinklagei (Engl.) Waterm. \\
4. & Zanthoxylum gillettii (De Wild) Waterm. \\
5. & Zanthoxylum lemairie (De Wild) Waterm. \\
6. & Zanthoxylum leprieurii (Guill ett Perr) Engl. Ex Waterm. \\
7. & Zanthoxylum rubescens (Planch ex. Hook. F.) Engl. Ex Watterm. \\
8. & Zanthoxylum tessmannii (Engl.) Ayafor Comb. nov. \\
9. & Zanthoxylum thomensee (Engl.) A. Chev. Mss ex Waterm. \\
10. & Zanthoxylum viride (A. Chev.) Waterm. \\
11. & Zanthoxylum zanthoxyloides (Lam.) Waterm. \\
\hline
\end{tabular}

These species were formerly known under the generic name Fagara Linn and it was recent chemosystematic considerations that led to the 'sinking' of Fagara. These eleven species of Zanthoxylum all belong to the sub-Family Rutoideae; tribe, Zanthoxyleae in the family Rutaceae and demonstrate (Olatunji, 1983) close similarities and relationships among themselves. The species, like other African Zanthoxylum species, are distinguishable by taxonomic characteristics-anatomical and morphological features of the root, leaf, fruit etc. They are all primarily plants of the forest vegetation and are found frequently in the Southern parts of Nigeria. Z. gillettii, Z. tessmannii and Z. leprieurii are trees and are common in the wet and dry forest vegetation of Southern Nigeria, with Z. gillettii, occurring more commonly in wetter locations along rivers, streams and wet valleys. Z. zanthoxyloides occurs more abundantly in the savannah and dry forest vegetations and is found in the drier parts of South Western Nigeria extending to Niger States. Z. rubescens occurs as a small tree, it is rather sparsely distributed throughout the Southern forest regions extending also into the northern parts of the country. Z. viridis has been recorded only in the drier parts of Oyo and Kwara States, Z. thomense in Ondo and Edo Sates and Z. lemairei in Edo and Benue States. Z. dinklagei occurs in Edo and the South Eastern State while Z. bouetense and Z. buesgenii are found only from the Oban forest in the South Eastern States, close to the Republic of Cameroon.

A major characteristic is that the trunks, branches, branchlets, leaf stalks and inflorescence axes of all these species are covered by prickles or what others describe (Waterman, 1986) as spines. This makes the Zanthoxylum species a big nuisance to farmers who always mark them for destruction when cited on farms and vegetations. Of value, however, is the characteristic that like a true Rutaceae, the leaflets and inflorescences of these species contain volatile oils which bring forth sweet smells/odours and fragrances.

\section{Economic and Medicinal Uses of the Zanthoxylum Species:}

Economically, the timber of Z. gillettii, Z. tessmannii, Z lemairei and Z. leprieurii are used (Dalziel, 1937; Oliver-Bever, 1982) in house and boat-building, decorative paneling, 
Afr. J. Trad. CAM (2005) 2 (3): 282 - 301

joinery, construction of talking drums and in the paper and pulp industry. The roots, bark and leaves of many species are used in various medicinal preparations for curing (Olatunji, 1983; Oliver-Bever, 1982) stomachache, tooth-ache, coughs, urinary and veneral diseases, leprous ulcerations, rheumatism, lumbago etc. They are used as components of antiseptic, antiparasitic and analgesic preparations for managing small pox, syphilis and related disease conditions. Since the root and stem bark of many species are poisonous to some species of water fleas, mice, fish and paramecia, these roots are used as vermifuge, febrifuge and piscicide.

Perhaps the most popular domestic use to which the roots are put is as chewing stick to clean the mouth. The roots usually give a warm, pungent and benumbing effect on the palate when chewed, and this aromatic warm taste with attendant profuse salivation is believed to be beneficial to the elderly and those with sore gums and other oral disease conditions.

\section{The Chemistry and Biological Values of the Nigerian Zanthoxylum}

The large pan-tropical genus Zanthoxylum Linn is very well known (Mester, 1983; Simanek, 1985) for its diverse chemistry, particularly of alkaloids, aromatic and aliphatic amides, sterols and phenylpropanoids-lignans and coumarins. These secondary metabolites are well distributed in the Zanthoxylum species investigated to date. It is equally interesting to note that scientific studies including selected biological leads, based on ethnomedical information have helped to discover new bio-active extracts and compounds some of which have good potentials for pharmaceutical development.

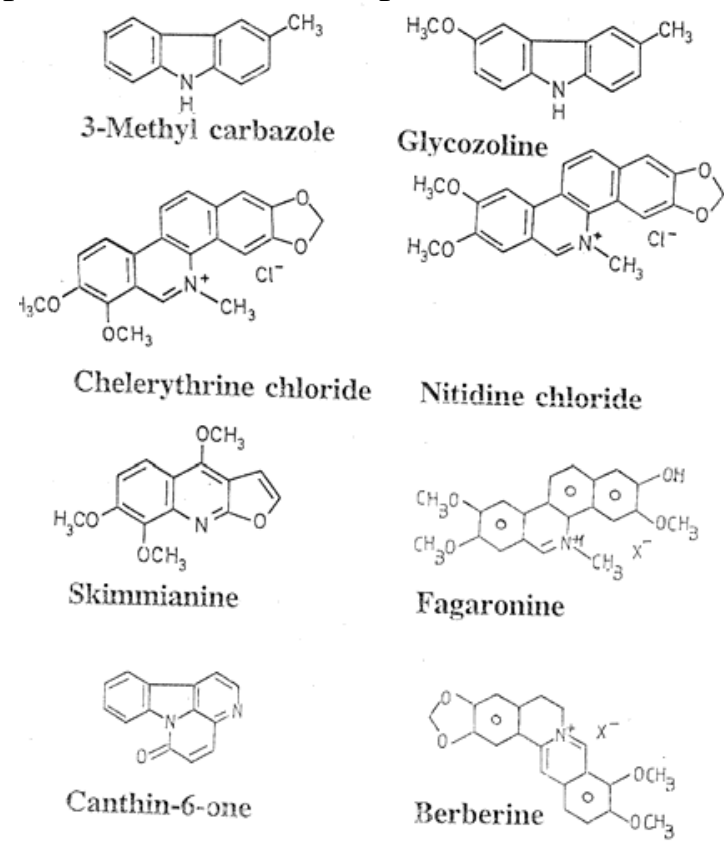

Figure 2: Structure of some alkaloids 
Afr. J. Trad. CAM (2005) 2 (3): 282 - 301

\section{Alkaloids in the Nigeria Zanthoxylum}

The Nigerian species of the sub-family, Rutoideae (Rutaceae) have proved to be a good source of the benzophenanthridine (Krane et al., 1984) and the aporphine alkaloids that typify the family (see Table 2.)

\section{Table 2: $\quad$ Alkaloid distribution in the Nigeria Zanthoxylum}

\begin{tabular}{|c|c|c|c|c|c|c|c|}
\hline Compound & $\begin{array}{l}\text { rubescens } \\
\text { RT.SB.FR }\end{array}$ & $\begin{array}{l}\text { zanthoxyloides } \\
\text { RT.SB.FR. }\end{array}$ & $\begin{array}{l}\text { leprieurii } \\
\text { RT.SB.FR }\end{array}$ & $\begin{array}{l}\text { tessmannii } \\
\text { RT.SB.FR. }\end{array}$ & $\begin{array}{l}\text { gillettii } \\
\text { RT.SB.FR }\end{array}$ & $\begin{array}{l}\text { thomense } \\
\text { RT.SB.FR }\end{array}$ & $\begin{array}{l}\text { lemairie } \\
\text { RT.SB.FR }\end{array}$ \\
\hline $\begin{array}{l}\text { BENZO- } \\
\text { PHENANTHRIDINES } \\
\text { 1.Nitidine } \\
\text { 2.Dihydronitidine } \\
\text { 3.Oxynitidine } \\
\text { 4.Fagaronine } \\
\text {.Dihydroavicine } \\
\text { 6.Chelerythrine } \\
\text { 7.Dihyrochelerythine } \\
\text { 8.Methoxychelerythine } \\
\text { 9.Norchelerythrine } \\
\text { 10.Oxychelerythrine } \\
\text { 11.Decarine } \\
\text { 12.Fagaridine }\end{array}$ & $\begin{array}{ll}\square & \\
& \\
\square & \\
\square & \square \\
\square & \square \\
\square & \square \\
\square & \\
& \square\end{array}$ & $\begin{array}{ll}\square & \square \\
\square & \\
\square \quad \square \\
\end{array}$ & $\begin{array}{ll}\square & \square \\
& \\
\square & \\
\square & \\
\square & \square \\
\square & \\
\square & \end{array}$ & $\begin{array}{ll}\square & \\
\square & \\
& \\
\square & \square \\
\square & \\
\square & \\
\square & \square \\
& \\
\square & \end{array}$ & $\begin{array}{ll}\square \quad \square & \square \\
\square & \square \\
\square & \\
\square & \\
\square & \\
\square & \end{array}$ & $\begin{array}{l}\square \\
\square\end{array}$ & $\begin{array}{ll}\square & \square \\
\square \quad & \square \\
\square \quad \square\end{array}$ \\
\hline $\begin{array}{l}\text { FUROQUINOLINES } \\
\text { 13.Dictamine } \\
\text { 14. 8-Methoxydictamine } \\
\text { 15.Skimmianine } \\
\text { 16.3-Dimethylallyl- } \\
\text { 4-methoxy-2-quinolone }\end{array}$ & $\square$ & $\begin{array}{l}\square \\
\square \\
\square\end{array}$ & $\square$ & $\begin{array}{l}\square \quad \square \\
\square\end{array}$ & $\begin{array}{ll}\square & \\
\square & \square \\
\square \quad & \square\end{array}$ & $\begin{array}{ll} & \square \\
\square & \square \\
\square & \square \quad \square\end{array}$ & $\square \quad \square$ \\
\hline $\begin{array}{l}\text { CARBAZOLES } \\
\text { 17. 3-Methylcarbazole } \\
\text { 18.Glycozoline }\end{array}$ & & & & & $\square$ & & $\square \quad \square$ \\
\hline $\begin{array}{l}\text { APORPHINES } \\
\text { 19.Berberine } \\
\text { 20.Tembetarine } \\
\text { 21.Magnoflorine } \\
\text { 22.N-methyl-corydine }\end{array}$ & $\begin{array}{l}\square \\
\square \\
\square\end{array}$ & $\begin{array}{l}\square \\
\square \\
\square \\
\square\end{array}$ & $\begin{array}{ll}\square & \square \\
\square & \end{array}$ & & $\square$ & & \\
\hline $\begin{array}{l}\text { CANTHINONES } \\
\text { 23. 6-Canthinone }\end{array}$ & & $\square$ & & & & & \\
\hline $\begin{array}{l}\text { ACRIDONES } \\
\text { 24.1-Hydroxy-3-Methoxy- } \\
\text { 10-Methylacridon-9-one } \\
\text { 25.1-Hydroxy-10- } \\
\text { Methylacridon-9-one } \\
\text { 26.Zanthozolin. }\end{array}$ & & & $\begin{array}{l}\square \quad \square \quad \square \\
\square \quad \square \quad \square \\
\square \quad \square \\
\end{array}$ & & & & \\
\hline
\end{tabular}

KEY: $\square$, compounds reported in literature, RT = root, SB = stem bark, FR = Fruit 
Afr. J. Trad. CAM (2005) 2 (3): 282 - 301

Carbazoles, canthinones and acridone alkaloids have also been found restricted to some species. Other alkaloids based on anthranilic acid or tryptophan are furoquinolines such as skimmianine which appear common to all the species investigated. Three acridone alkaloids have been isolated (Reisch et al., 1985) from the root, stem and pericarps of Zanthoxylum leprieurii. The benzophenanthridines, nitidine and chelerythrine, the furoquinoline, skimmianine and the aporphines, berberine, magnoflorine etc. have all been isolated (Vaquette et al., 1978) from Zanthoxylum bouetense and Zanthoxylum dinklagei roots and stem bark.

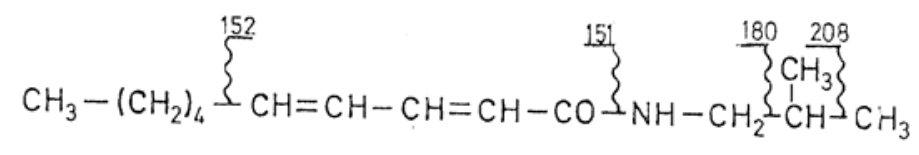

I, (2E, 4E)-N-isobutyl-2,4-decadienamide

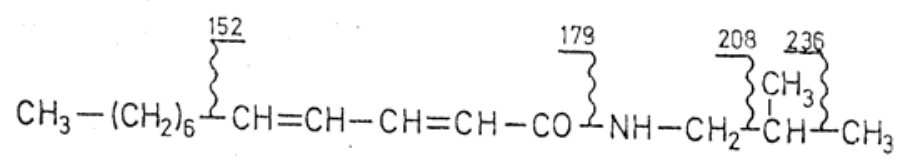

II, (2E,4E)-N-isobutyl-2,4-dodecadienamide
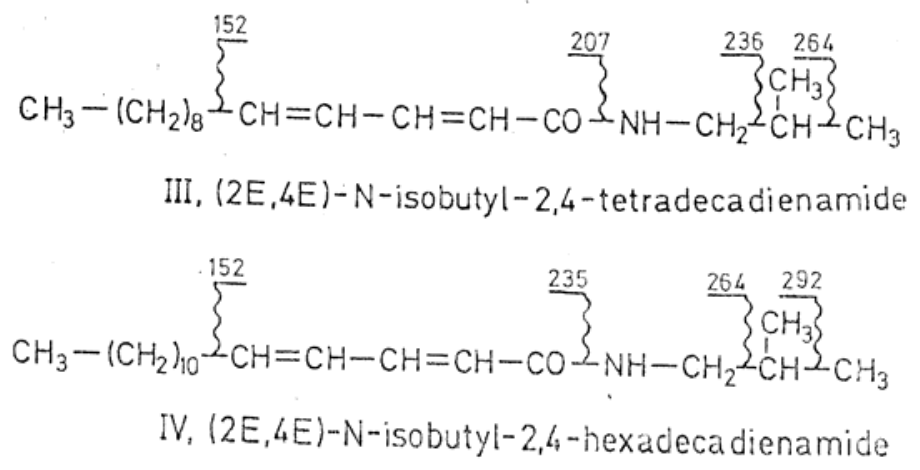

Figure 3: Some aliphatic amides

Despite the fact that there are no known folkloric reports of their use in the management or cure of tumours and cancerous conditions, scientists have been attracted because of the antileukemic properties and other values of the isolates from these plants. Nitidine isolated (Arthur et al., 1958) from Zanthoxylum nitidum in 1958 and later from (Fish and Waterman, 1971) Fagara macrophylla (Zanthoxylum macrophylla) in 1971 demonstrated strong antileukemic activities (Wall et al., 1987) against L1210 and P388 and showed growth inhibition of Lewis lung carcinoma. It was also found to be marginally active against $B 16$ melanoma. A phenolic benzo[C] phenanthridine, fagaronine, was isolated (Messmer et. Al., 1972) from Zanthoxylum zanthoxyloides as the active principle demonstrating strong antileukemic activity against both L 1210 and P-388 leukemia in 1972. It gave prolongations of life of the order of 265, 210 and 190\% T/C at doses of 100, 50 and $25 \mathrm{mg} / \mathrm{kg}$ respectively. The benzophenanthridine alkaloids of the Zanthoxylum generally show some anti-neoplastic activities but their toxicities have been found to be a serious problem; this has also prevented them from clinical use. 
Afr. J. Trad. CAM (2005) 2 (3): 282 - 301

The acridone class of alkaloids has been surveyed with special emphasis on experimental cancer chemotherapy studies of acronycine. Studies on acronycine's broad antitumour spectrum and its toxicity have been carried out (Gerzon and Svoboda, 1983) as a prelude to an introduction to its clinical evaluation in patients. The mode of action of acronycine reportedly involves its incorporation into cellular and subcellular membranes resulting in the inhibition of nucleoside. Further studies need to be carried out on these group of compounds which have been found to lack activity against the four primary tumour models rightly held to be of high predictive merit for clinical efficacy. Acridone alkaloids isolated from Z. leprieurii have shown antibacterial effect.
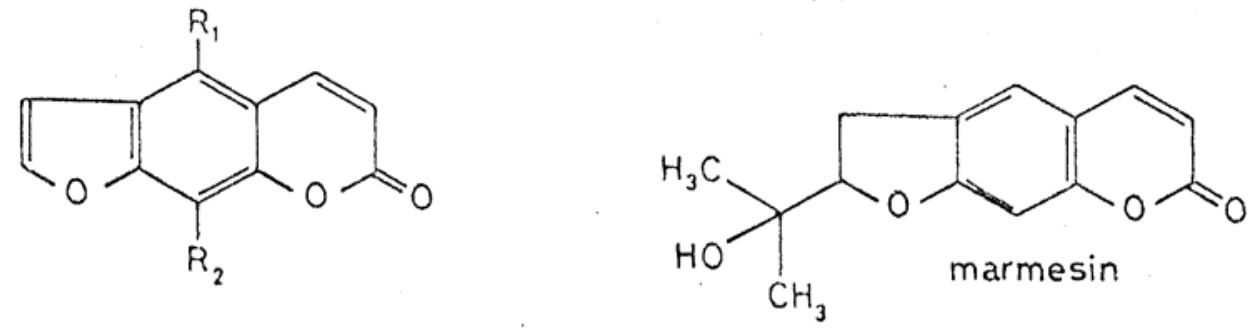

$$
\begin{array}{ll}
\text { psoralen } & \mathrm{R}_{1}=\mathrm{R}_{2}=\mathrm{H} \\
\text { bergapten } & \mathrm{R}_{1}=\mathrm{OCH}_{3}, \mathrm{R}_{2}=\mathrm{H} \\
\text { xanthotoxin } & \mathrm{R}_{1}=\mathrm{H}, \mathrm{R}_{2}=\mathrm{OCH}_{3} \\
\text { imperatorin } & \mathrm{R}_{1}=\mathrm{H}, \mathrm{R}_{2}=\mathrm{OCH}-\mathrm{CH}=\mathrm{C}\left(\mathrm{CH}_{3}\right)_{2} \\
\text { xanthotoxol } & \mathrm{R}_{1}=\mathrm{H}, \mathrm{R}_{2}=\mathrm{OH}
\end{array}
$$<smiles>[R]c1cc2ccc(=O)oc2cc1[R]</smiles>$$
\text { umbelliferone } \mathrm{R}_{2}=\mathrm{OH}, \mathrm{R}_{1}=\mathrm{H}
$$$$
\text { scoparone } \quad \mathrm{R}_{1}=\mathrm{R}_{2}=\mathrm{OCH}_{3}
$$$$
\text { scopoletin } \quad \mathrm{R}_{1}=\mathrm{OH}, \mathrm{R}_{2}=\mathrm{OCH}_{3}
$$

Figure 4: Coumarins in the Nigerian Zanthozylum

Paris and his co-workers observed that a crude extract of F. macrophylla root $(0.1 \mathrm{~g} / \mathrm{kg})$ caused bradycardia and hypotension in dogs (Paris and Moyse-Mignon, 1951). The isolated pure alkaloid was found to lower both the systolic and diastolic blood pressures. This finding was confirmed by Addae-Mensah and his co-workers (Addae-Mensah et al., 1986). A single dose of nitidine chloride $(1-2 \mathrm{mg} / \mathrm{kg}$ ) lowered the blood pressure by about $20 \%$ within 90 minutes and this was maintained for up to six hours. Doses of 500, 600, 700, 800 and 900 $\mathrm{mg} / \mathrm{kg}$, administered at 80 minutes intervals, cumulatively lowered the blood pressure by about 25\%. The drug also antagonized the effects of angiotension-induced hypertension. Its delayed introduction into clinical medicine may have been informed by its reported toxicity.

The benzophenanthridine, chelerythrine and aporphine, berberine, and the phenolic canthine-6-one isolated from the powdered root of Fagara zanthoxyloides have also been identified (Odebiyi and Sofowora, 1973) with antimicrobial activity. These show that the 


\section{Afr. J. Trad. CAM (2005) 2 (3): 282 - 301}

alkaloids of the Zanthoxylum have shown anti-tumour, anti-hypertensive and anti-microbial effects.

\section{Amides in the Zanthoxylum:}

The hot, peppery taste of the Zanthoxylum roots is a common feature of all the roots known. The benumbing effect on the pallate when chewed is characteristic and has been used to advantage in the treatment of mouth infections particularly in the elderly.

The genus Zanthoxylum is characterized (Mester, 1983; Fish and Waterman, 1973) chemically by the frequent accumulation of olefinic alkamides (unsaturated aliphatic acid amides), a biogenetic capacity derived from the condensation of fatty acids such as linolenic and linoleic acids with isobutyl amines. By 1963, Bowden and Ross identified the hot peppery component of the root of Zanthoxylum zanthoxyloides as pellitorine (Bowden and Ross, 1963), "the local anaesthetic component" of the roots. This property had earlier on been noted by Paris and Mignon in 1947. Pellitorine and many other structurally-related components, for example, $\mathrm{N}$-isobutyl-trans-2-trans-4-octadienamide, $\mathrm{N}$-isobutyl-trans-2trans-4-tetradecadienamide, N-isobutyl-trans-2-trans-4-eicosadienamide, gamma-sanshool (N-isobutyl-2,4,8,10,12-tetradecapentaenamide) which are pungent, have been isolated Mizutani et al., 1988; Gregor, 1984; Adesina et al., 1997) from Zanthoxylum lemairie and many other Zanthoxylum species and have been implicated for the organoleptic properties of the roots. Seven of such amides have been described in the Nigerian Zanthoxylum (see Table 3.) The structural type and concentration of each amide appear very relevant in considering how pungent the roots are.

\section{Table 3: $\quad$ Distribution of aliphatic amides in the Nigerian Zanthoxylum}

\begin{tabular}{|c|c|c|c|c|c|c|c|}
\hline Compounds & $\begin{array}{l}\text { rubescens } \\
\text { RT.SB.FR }\end{array}$ & $\begin{array}{l}\text { zanthoxyloides } \\
\text { RT.SB.FR. }\end{array}$ & $\begin{array}{l}\text { leprieurii } \\
\text { RT.SB.FR. }\end{array}$ & $\begin{array}{l}\text { tessmanni } \\
\text { RT.SB.FR. }\end{array}$ & $\begin{array}{l}\text { gillettii } \\
\text { RT.SB.FR. }\end{array}$ & $\begin{array}{l}\text { thomense } \\
\text { RT.SB.FR. }\end{array}$ & $\begin{array}{l}\text { lemairie } \\
\text { RT.SB.FR. }\end{array}$ \\
\hline $\begin{array}{l}\text { ALIPHATIC AMIDES } \\
\text { 1.N-isobutylocta2,4- } \\
\text { dienamide } \\
\text { 2.N-Isobutyldeca,2,4- } \\
\text { dienamide } \\
\text { 3.N-Isobutyldodeca2,4- } \\
\text { dienamide } \\
\text { 4.N-Isoutyltetradeca 2,4- } \\
\text { dienamide } \\
\text { 5.N-Isobutylhexadeca-2,4- } \\
\text { dienamide } \\
\text { 6.N-Isobutyleicosa-deca } \\
\text { - 2,4-dienamide } \\
\text { 7.N-Isobutyl-2,4,8,10,12 } \\
\text { tetradecapentaenamide. }\end{array}$ & $\begin{array}{c}\square \\
\square \quad \square \quad \square \\
\\
\square \quad \square \quad\end{array}$ & $\begin{array}{ccc}\square & \square & \square \\
\square \quad & \square \quad & \square \\
& & \\
& & \square\end{array}$ & $\square$ & $\begin{array}{ll}\square & \square \\
\square & \square \\
\square & \square \\
\square & \square\end{array}$ & $\begin{array}{lll}\square & \square \\
\square \quad & \square & \\
\square \quad & \square & \\
\square \quad & \square \quad \square\end{array}$ & $\begin{array}{ll}\square & \square \\
\square & \square\end{array}$ & $\begin{array}{ll}\square \quad \square \\
\\
\square \quad \square \\
\square \\
\square \quad \square \\
\square \quad \square\end{array}$ \\
\hline
\end{tabular}

KEY: $\square$, compounds reported in literature. 
Afr. J. Trad. CAM (2005) 2 (3): 282 - 301

Biologically, the isobutyl amides have been shown to have strong insecticidal properties. The main component of pellitorine, $\mathrm{N}$-isobutyldeca-trans-2-trans-4-dieanamide is very potent causing (Gregor, 1984; Yasuda et al., 1981) marked paralysis of mucous membranes and was about half as toxic as the pyrethrins to the house fly, Musca domestica L. It has also been found to show antibacterial and antimalarial properties Weenen et. al., 1990). On the other hand N-isobutyldodeca-2,4-dienamide obtained from four Zanthoxylum species is only weakly pungent and is inactive to house flies (Yasuda et. al., 1981; Jacobson, 1954). Kubo and his co-workers have confirmed that pellitorine isolated from Fagara macrophylla was a potent insecticide.
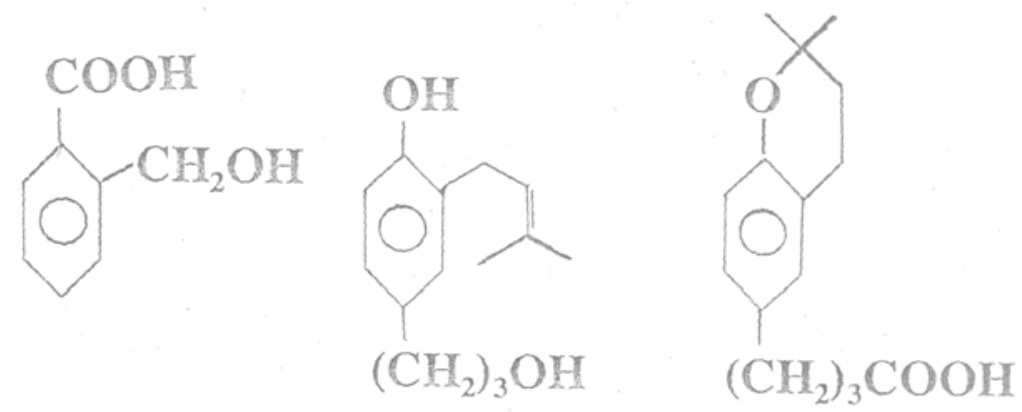

2-Hydroxymethyl Zanthoxylol benzoic acid

DBA

Figure 5: Compounds with anti-sickling properties

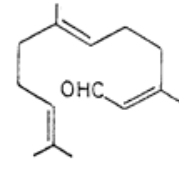

Farnesa!

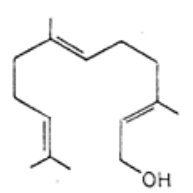

Farnesol

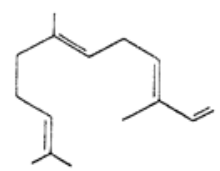

$\alpha$-Farnesene

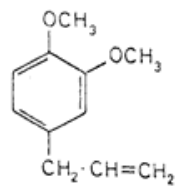

Methyleugenol

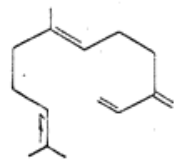

$\beta$-Farnesene

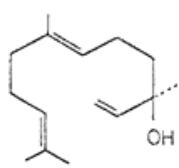

Nerolidol

Figure 6: Volatile oil constituents of the Nigerian Zanthoxylum 


\section{Afr. J. Trad. CAM (2005) 2 (3): 282 - 301}

Some olefinic isobutylamides have also been shown (Yasuda et. al., 1981; Kubo et. al., 1984) to be effective as molluscides and cercaricides and are thus of potential use against bilharzia. Alkamides have been used medicinally since ancient times as sialogogues, antitussive and analgesic and their presence in the Zanthoxylum may be of immense benefit to medicine.

The other type of amides encountered in the Zanthoxylum are the aromatic amides described occasionally also as alkaloids or trans-cinnamoylamides. The roots, stem-barks and pericarps of all the seven Zanthoxylum species examined have been found to contain amides, but the structural types and concentrations of these amides vary from one species to the other. In all, over twenty aromatic amides have been identified in the Nigerian Zanthoxylum (see Table 4.)

Table 4: Distribution of aromatic amides in the Nigerian Zanthoxylum

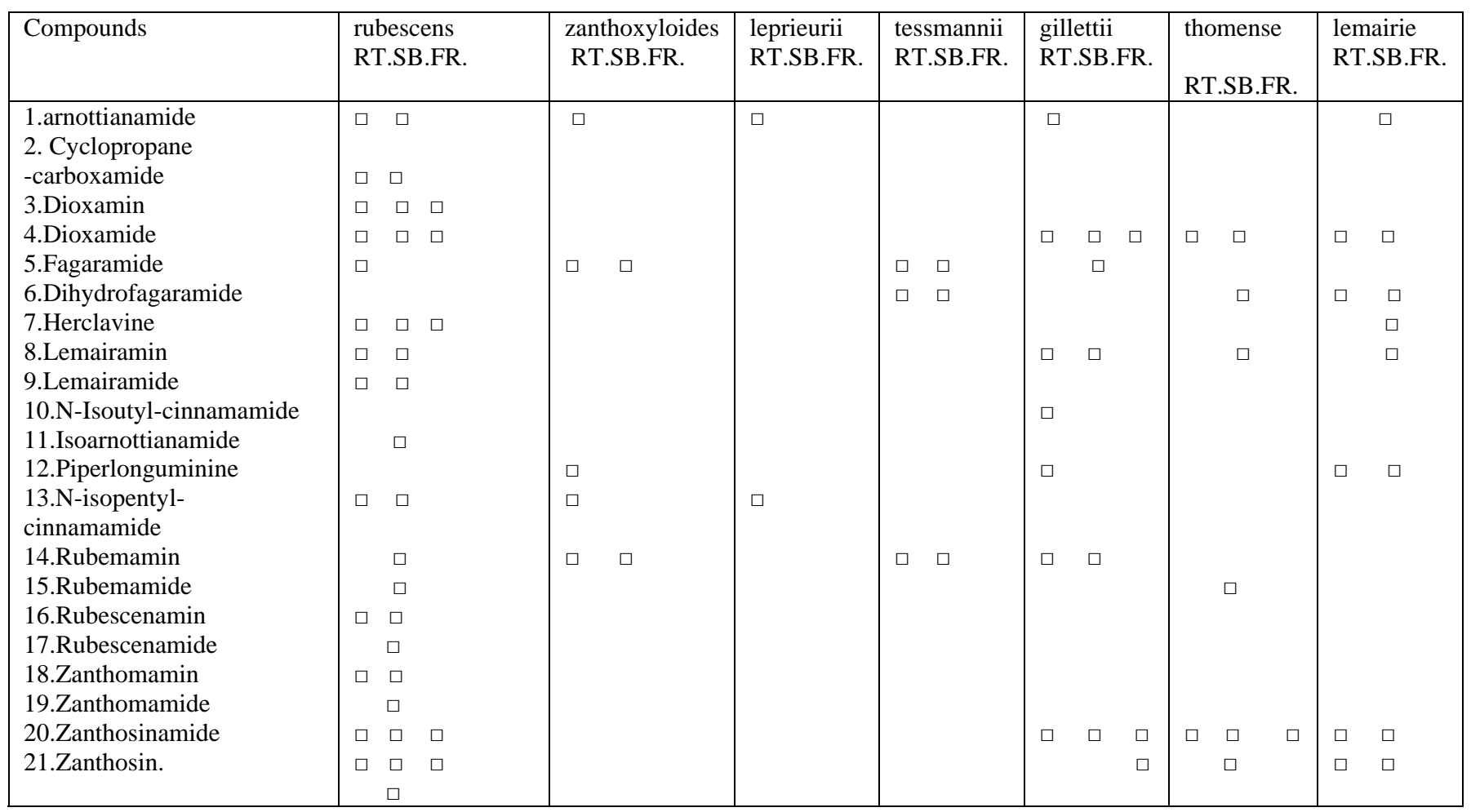

KEY: $\square$, compounds reported in literature

While $Z$. rubescens and $Z$. gillettii appear to be very rich in aromatic amides, only a few have been identified in Z. leprieurii. This peculiarity is interesting, when one notes that it is only $\mathrm{Z}$. leprieurii that accumulates acridone alkaloids in its organs.

Some of the identified amides have the 6C-3C- or $6 \mathrm{C}-2 \mathrm{C}-\mathrm{N}$ unit in their molecules and this indicates that, in part, they have originated from the tyrosine/p-coumaric acid pathway. 


\section{Afr. J. Trad. CAM (2005) 2 (3): 282 - 301}

Fagaramide which was detected in all but one of the species investigated has a cinnamic acid moiety combined with isobutylamine which itself may have originated from the amino acid, valine. Many of the amides share this structural type or their derivatives. Herclavine identified in Z. rubescens. Z. lemairie and Z. thomense appears to be a direct product of tyrosine, p-coumaric acid condensation. Unlike arnottianamide and its isomer which are oxidation products of chelerythrine and nitidine respectively (Ishii et al., 1976), all these amides are condensation products of cinnamic acid derivatives and those of amino acids. Very recently, fagaramide was identified alongside with piperlonguminine, herclavine, zanthomamide, zanthosinamide, lemairamin and lemairamide from Zanthoxylum lemairie Adesina et al., 1997a; Adesina et al., 1997b). Fagaramide had earlier on been found to demonstrate weak anti-inflammatory effects (Oriowo, 1982) in laboratory animals, suggesting that structurally-related compounds may also show this effect. Of value also is the report that fagaramide is a more active molluscicide against Biomphalaria glabratus than piperlonguminine (Kubo et. al., 1984).

Zanthoxylum rubescens appears to occupy a unique position as many aromatic amides have been isolated (Adesina and Reisch, 1989) from the root and stem bark. These include N(3,4-dimethoxyphenylethyl)-3,4-dimethoxy-cinnamamide (rubemamin), N-methyl, N-3,4dimethoxyphenylethyl_-3,4-dimethoxycinnamamide (rubemamide), N-methyl, N-(3,4methylenedioxyphenylethyl)-3,4-methylenedioxycinnamamide (dioxamide) and $\mathrm{N}$-(3,4methylenedioxyphenylethyl)-3,4-methylenedioxycinnamamide (dioxamin) isolated from the roots in 1989. Three other unsaturated aromatic amides, N-methyl, N-(3,4methylenedioxyphenylethyl), 3,4-(dimethoxycinnamoylamide (rubescenamide), N-(3,4dimethoxyphenylethyl, 3', 4-methylenedioxycinnamoylamide (zanthosin) were isolated also from the stem bark. When tested for anticonvulsive effects in mice, dioxamin and rubemamin separately showed strong anticonvulsive effects in laboratory animals. This probably explains the strong anticonvulsive effects of $Z$. rubescens stem and root bark extracts.

\section{Phenylpropanoids in the Nigerian Zanthoxylum:}

Phenylpropanoids are perhaps the most widespread types of natural products occurring in nature. Chemical investigations on the whole root, stem and aerial parts of all the Zanthoxylum species collected revealed simple coumarins only. Aesculetin dimethylether (scoparone) and 6,7,8-trimethoxy coumarin were present in all these species (Table 5). Furocoumarins were detected in two species only, in Z. zanthoxyloides and Z. lemairei. Surprisingly, however, there has not been a known report of any coumarin in Zanthoxylum rubescens.

Biologically, coumarins are very useful and many of them have exhibited (Mabry and Ulubelen, 1980) antibacterial, anti-tumour, vasodilatory (in coronary vessels) and anticoagulant activities. It was long noted that most coumarins are free from toxic side effects and may be given for years without side effects; overdose, however, causes haemorrhages (Lau-Cam and Chu-Fong, 1972). 
Afr. J. Trad. CAM (2005) 2 (3): 282 - 301

Table 5: $\quad$ Distribution of coumarins in the Zanthoxylum

\begin{tabular}{|c|c|c|c|c|c|c|c|}
\hline Compounds & $\begin{array}{l}\text { rubescens } \\
\text { RT.SB.FR. }\end{array}$ & $\begin{array}{l}\text { zanthoxyloides } \\
\text { RT.SB.FR. }\end{array}$ & $\begin{array}{l}\text { leprieurii } \\
\text { RT.SB.FR } \\
\end{array}$ & $\begin{array}{l}\text { tessmannii } \\
\text { RT.SB.FR. }\end{array}$ & $\begin{array}{l}\text { gillettii } \\
\text { RT.SB.FR. }\end{array}$ & $\begin{array}{l}\text { thomense } \\
\text { RT.SB.FR. }\end{array}$ & $\begin{array}{l}\text { lemairie } \\
\text { RT.SB.FR. }\end{array}$ \\
\hline $\begin{array}{l}\text { 1.Umbelliferone } \\
\text { 2.Scopoletin } \\
\text { 3.Scoparone } \\
\text { 4.6,7,8-trimethoxy- } \\
\text { coumarin } \\
\text { 5.Xanthotoxin } \\
\text { 6.Imperatorin } \\
\text { 7.Bergapten } \\
\text { 8.Marmesin } \\
\text { 9.Pimpinellin } \\
\text { 10.Xanthyletin }\end{array}$ & & 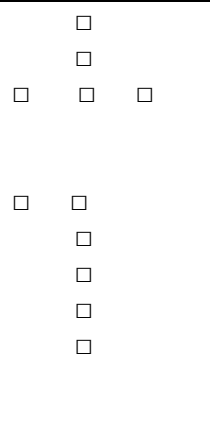 & $\begin{array}{l}\square \quad \square \\
\square \quad \square\end{array}$ & $\begin{array}{l}\square \quad \square \\
\square \quad \square\end{array}$ & $\begin{array}{l}\square \quad \square \\
\square \quad \square\end{array}$ & $\begin{array}{l}\square \quad \square\end{array}$ & $\begin{array}{ll}\square & \square \\
\square & \square \\
& \\
\square & \square \\
\square & \end{array}$ \\
\hline
\end{tabular}

KEY: $\square$, compounds reported in literature

Some coumarins such as umbelliferone, scopoletin, scoparone and the furocoumarins-xanthotoxin, imperatorin, bergapten, marmesin etc, isolated from the Zanthoxylum (Adesina, 1986), have shown antibacterial and antifungal activities (Mabry and Ulubelen, 1980). The coumarins inhibit the growth of the yeast Saccharomyces cerevisiae and at higher concentrations retard the germination of the spores of Aspergillus niger and Penicillin glaucum. Furocoumarins also have the potential of snail control by exerting a molluscicidal activity (Mabry and Ulubelen, 1980; Adesina and Adewunmi, 1985), comparable to some of the most powerful synthetic agents and these probably contribute in part to the molluscicidal activities of Zanthoxylum zanthoxyloides root-bark extracts. Furocoumarins have also been used (Mabry and Ulubelen, 1980) to treat vitiligo and psorasis. Both scoparone and scopoletin have demonstrated (Ojewole and Adesina, 1983; Jamwal et al., 1972) marked anticonvulsive effects in experimental animals and have been found to be the major active compound of some plants implicated in the management of convulsions.

The phenylpropanoids described as lignans are also widely distributed in higher plants and more than 200 compounds have been identified. They are biogenetically derived (Mabry and Ulubelen, 1980; Massnaet et al., 1989) by the oxidative dimerisation of two $\mathrm{C}_{6}-\mathrm{C}_{3}$ units, that is, two characteristic phenylpropanoid units. The degree of oxidation and types of substituents determine the emerging lignan structure. There are also naturally occurring dimers that exhibit peculiar-type linkages. Only two structural types of lignans have been encountered in the Nigeria Zanthoxylum and these are (1) those lignans containing the 2,3-bis (substituted benzyl) $-\gamma$-butyrolactone unit, for example, arctigenin methylether, hinokinin, savinin, 2,3-Di (3',4'-methylenedioxybenzyl)-2-buten-4-olide isolated from Z. lemairei 
Afr. J. Trad. CAM (2005) 2 (3): 282 - 301

(Adesina et al. 1997a) and (2), those containing 2, 6-diaryl-3, 7-dioxabicyclo (3-3-0) octane ring structure typified by sesamin. Apart from the nine lignans previously reported in the Nigerian Zanthoxylum (Table 6), five other lignans $-2 \alpha$ and $2 \beta$-vertrylmethyl-3 $\alpha$ piperonylmethyl- $\gamma$-butyrolactones, kubosin, guayadequine and methyl trachelogeinin were recently described from $Z$. lemairei (Adesina et al. 1997a).

Table 6: $\quad$ Distribution of lignans in the Zanthoxylum

\begin{tabular}{|c|c|c|c|c|c|c|c|}
\hline Compounds & $\begin{array}{l}\text { rubescens } \\
\text { RT.SB.FR }\end{array}$ & $\begin{array}{l}\text { zanthoxyloides } \\
\text { RT.SB.FR. }\end{array}$ & $\begin{array}{l}\text { leprieurii } \\
\text { RT.SB.FR }\end{array}$ & $\begin{array}{l}\text { tessmannii } \\
\text { RT.SB.FR. }\end{array}$ & $\begin{array}{l}\text { gillettii } \\
\text { RT.SB.FR }\end{array}$ & $\begin{array}{l}\text { thomense } \\
\text { RT.SB.FR }\end{array}$ & $\begin{array}{l}\text { lemairie } \\
\text { RT.SB.FR. }\end{array}$ \\
\hline $\begin{array}{l}\text { 1.Sesamin } \\
\text { 2.Asarinin } \\
\text { 3.Savinin } \\
\text { 4.Hinokinin } \\
\text { 5.Arctigenin- } \\
\text { methylether } \\
\text { 6.Arctigenin } \\
\text { 7.Matairesinol } \\
\text { 8.2,3-Di(3'4' } \\
\text { methylenedioxy- } \\
\text { benzyl)-2-buten-4-olide } \\
\text { 9.Lirioesinol- } \\
\text { dimethylether }\end{array}$ & & $\begin{array}{lll}\square & \square & \square \\
\square & & \end{array}$ & $\begin{array}{l}\square \\
\square\end{array}$ & $\begin{array}{lll}\square & \square & \\
\square & \square & \square \\
\square & & \\
\square & \square & \\
\square & & \\
\square & & \\
\square & & \end{array}$ & $\begin{array}{lll}\square & \square & \square \\
\square & \square & \\
\square & \square & \\
\square & \square & \square \\
\square & \square & \square \\
\square & & \\
\square & & \end{array}$ & $\begin{array}{ll}\square & \square \\
\square & \square \\
& \\
& \\
\square & \square\end{array}$ & 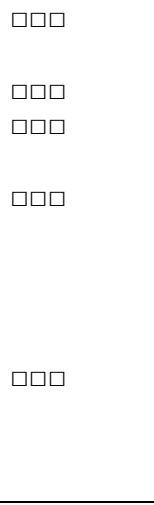 \\
\hline
\end{tabular}

KEY:

$\square$, compounds reported in literature .

The range of lignan structures and biological activities (Massnaet et al., 1989; MacRae and Towers, 1984) is broad. Various lignans are known to have anti-tumor, anti-mitotic and antiviral activity and to specifically inhibit certain enzymes. At the ecological level, there is the evidence that lignans play a role in plant-fungus, plant-plant and plant-insect interactions. Some lignans are toxic to fungi and insects. Other physiological properties of lignans have also been observed. Sesamin, for example, has been used (Vickery et. al., 1950) as an antioxidant. Sesamin and asarinin are effective in enhancing the toxicity of a wide variety of insecticides and have themselves been used as insecticides. These lignans have been used (Hallen et. al., 1942) as synergists, like known synthetic insecticide synergists, with other insecticides such as pyrethrins. Of particular interest is the fact that savinin, hinokinin, matairesinol and its dimethylether are all insecticide synergists. Trachelogenin and arctigenin were found to demonstrate potent and long-lasting antihypertensive effects on spontaneously hypertensive rats (Ichikawa et al., 1986). It is not known whether methyl trachelogenin and arctigenin dimethyl ether also isolated (Adesina et al., 1997a) from the Nigerian Zanthoxylum will show this effect. These bisepoxy lignans kobusin and sesamin were shown to inhibit the growth of silkworm (Bombyx mori) larvae; thus demonstrating antifungal effects. 
Afr. J. Trad. CAM (2005) 2 (3): 282 - 301

\section{Other Extractives from the Nigerian Zanthoxylum}

Chemical studies (Eshiett and Taylor, 1966; Eshiett and Taylor, 1968) of some Zanthoxylum species led to the isolation and characterization of zanthoxylol identified as 3dimethylallyl-4-hydroxyphenyl propanol from Fagara zanthoxyloides among other compounds. This plant has also furnished diosmin, fagarol and hesperidin (Okogun, et al., 1978).

Sterols are common components of many plants and have been isolated from virtually all plants. Whereas $\beta$-sitosterol appears ubiquitous in nature, the triterpene lupeol appears restricted to the Zanthoxylum. Lupeol, $\beta$-sitosterol, usually associated with stigmasterol and campesterol and $\beta$-amyrin have been isolated from the various morphological parts of all the Zanthoxylum species investigated.

The results of biological work on $\beta$-sitosterol has been very interesting indeed. This compound was found to possess potent anti-inflammatory activity (Gupta et al., 1980) similar to hydrocortisone and oxyphenbutazone when administered intraperitoneally. This compound was also orally effective against carrageenin-induced oodema. The anti-inflammatory activity of this compound was independent of pituitary adrenal axis. $\beta$-sitosterol also exhibited antipyretic activity similar to acetylsalicylic acid. $\beta$-sitosterol was found to show a wide margin of safety since the approximate $\mathrm{LD}_{50}$ was more than $3 \mathrm{~g} / \mathrm{kg}$ i.p. in mice and minimum ulcerogenic dose was $600 \mathrm{mg} / \mathrm{kg}$ i.p. in rats. Because of these properties and the wide margin of safety, $\beta$-sitosterol may be of therapeutic value.

Of great interest too is the isolation and identification of antifungal and antioxidant compounds from the root bark of Fagara zanthoxyloides (Chaaib et al., 2003).

\section{The Zanthoxylum Species in the Management of Sickle-cell Disease (SCD)}

The interesting story of Fagara zatthoxyloides (syn. Zanthoxylum zanthoxyloides) probably started in this environment with the observation or chance discovery by El-Said (ElSaid et al., 1971) and his team in 1971 that the Fagara root extract possessed activity on the red cell membrane. El- Said and his collaborators reported that the extract of this plant, apart from being antibacterial preserved the colour of the blood within its zones of inhibitions when examined on blood agar plates. Sofowora and Isaacs (1971) later reported on the reversal of sickling and crenation in erythrocytes by the root extract of Fagara zanthoxyloides. Both authors and their associates have separately reported these effects at different scientific meetings (Isaac-Sodeye, 1973;Sofowora, 1974; Isaac-Sodeye et al., 1975). In 1975, Sofowora and his team reported the isolation and characterization of 2-hydroxymethyl benzoic acid as one of the anti-sickling agents of the plant (Sofowora et al., 1975).

Though Honig et al, adopting a different methodology of evaluation and working on plant specimens purportedly collected in Ghana could not confirm these effects (Honig et al., 1975), Sophia Abu and his collaborators confirmed the antisickling effects of Fagara zanthoxyloides root extract (Abu et al., 1981). Since then, biological and chemical assays have been developed for the estimation of antisickling agents in the roots of many Nigerian Zanthoxylum species (Elujoba and Sofowora, 1977; Adeoye, 1978; Adesanya, 1980). Very 


\section{Afr. J. Trad. CAM (2005) 2 (3): 282 - 301}

recently, in 1989, Osoba and his team studied the effect of the root extract of Zanthoxylum zanthoxyloides and some selected substituted benzoic acids on glucose-6-phosphate and 6phosphogluconate dehydrogenases in HBSS red blood cells and found out that the antisickling fraction of the root of $Z$. zanthoxyloides, vanillic acid, p-hydroxy benzoic acid and p-fluoro benzoic acid possessed antisickling inhibitory activity at low concentrations Osoba et al., 1989). The authors found out that p-fluorobenzoic acid was the most active. It was also noted that the agent did not affect the activities of glucose-6-phosphate and 6phosphogluconate dehydrogenases while exhibiting antisickling activity nor disrupt the cell membrane to the extent of causing leakage to the media.

The quest for ant-sickling agents continued in other laboratories with time. In preliminary assays carried out at the Universitty of Ibadan, Isaacs Sodeye noted that it seemed that zanthoxylol isolated from Zanthoxylum zanthoxyloides in 1966 possessed antisickling activity. Zanthoxylol was modified chemically to 3,4-dihydro-2,2-dimethyl-2H-1benzopyran-6-butyric acid (DBA). This compound was found to efficiently prevent and reverse sickling (Ekong et al., 1975). It also had no acute toxicity in male mice. Zanthoxylol has since been isolated and estimated from the root of Zanthoxylum zanthoxyloides (Elujoba and Nagels , 1985) the only Nigerian Zanthoxylum in which it was detected.

In very recent times, Fadulu, (a former associate of El-Said, Kuye and Sofowora) and his American collaborators reported a potent anti-sickling compound code-named NX-06999 (The World Sickle Cell Foundation Inc., 1990). It was reported to be free from any toxic side effects and was already being subjected to preliminary clinical trials in Nigeria, Gabon and Panama. There is, therefore, no doubt that Zanthoxylum extracts and the "unknown antisickling candidate" coded NX-06999 had some promise as possible additions to the regime of managing Sickle Cell Disease. A most recent report by Ouattara et al. ( 2004) of the analysis of isomeric divanilloylquinic acids from the root bark of Fagara zanthoxyloides Lam. is of great scientific interest. The new isomeric divanilloylquinic acids- 3,4-Odivanilloylquinic acid, 3,5-O-divanilloylquinic acid and 4,5-O-divanilloylquinic acids were obtained from the roots of Fagara zanthoxyloides Lam. collected in Burkina Faso. The authors concluded that these new compounds named burkinabins A-C could play a useful role in sickle cell disease as the active agents of the root of Fagara zanthoxyloides previously referred to as unidentified aromatic compounds by Adesanya and Sofowora .

\section{Zanthoxylum gum (Rutaceae)}

The dried gummy exudates from the stem of many trees or plants are used by pharmaceutical industries as binder, emulsifying agent or even as a diluent. The composition of the exudates vary very much in the contents of ash or carbohydrate moieties etc and these usually influence the properties of these gums. Gum arabic, (from Acacia species), for instance, is principally Calcium, Magnesium and Potassium salts of the polysaccharide acid, arabic acid and is used extensively as a suspending agent for insoluble substances in water, in the preparation of emulsions and for making pills and troches. It has also been used for its demulcent action in inflammations of the throat or stomach. Similarly, the dried gummy exudation, gum tragacanth or Hog Gum from Astragalus gummifer (Leguminosae), contains $60-70 \%$ of bassorin and 30-40\% soluble gum tragacanthin. Bassorin consists of complex 
Afr. J. Trad. CAM (2005) 2 (3): 282 - 301

methoxylated acids resembling pectin in tragacanthin which yields carbohydrate moieties, mainly glucuronic acid and arabinose on acid hydrolysis. The pharmaceutical industries have found gum tracaganth a useful suspending agent in lotions, mixtures and extemporaneous preparations and prescriptions; as a pill excipient and in various confectionary products.

Some investigations were carried out on the gum collected as dried tears from the slashed bark of Zanthoxylum tessmannii. The gum was analysed for ash, carbohydrate residues and a peroxidase enzyme. The studies (Orafidiya et al., 1992a) were limited to some physico-chemical properties of the gum, the rheological properties (Orafidiya, 1989) of aqueous solution of the gum and some factors affecting (Orafidiya et al., 1992b) the stability of emulsions prepared for it. There is still the need for more investigations regarding its binding and gliding capabilities and the properties of gums from other Zanthoxylum species.

\section{Natural Volatile Concentrates}

Many plants are able to accumulate volatile odoriferous substances in order to attract insects or other animals for pollination and seed dispersal, to repel others which may be harmful or to protect themselves from pathogenic micro-organisms.

In recent times, these odoriferous substances, mainly volatile oils have been put into good use by man. These include (1), direct culinary use as fresh or dried herbs, spices and condiments; (2), in perfumery, cosmetic and house-hold and personal hygiene products; (3), as flavors in food, drink and confectionery; (4), as components of pharmaceutical preparations in human and veterinary medicine; (5), as pesticides as insect repellents in agriculture particularly crop protection and (6), as anti-infective agents, particularly as anti-bacterial and anti-fungi agents. The rich volatile oils have also found ample use in many industrial institutions.

Like Citrus species (Rutaceae) which accumulate volatile oils with strong antiseptic and disinfectant properties in the fresh fruit, peel, leaves and dried fruit, the Zanthoxylum species also accumulate volatile oils in the leaves, fruit and inflorescences. For example the volatile constituents (Reisch et al., 1986) of Z. macrophylla pericarp include $\alpha$-pinene, limonene, linalool, methyl eugenol, guaiene and other components while nerolidol and farnesol derivatives have been found in high quantities in the pericarp of Zanthoxuylum tessmannii. There is no doubt that the volatile oils of the leaves, fresh flowers and fruits of these Zanthoxylum species will give good yields of volatile oils if exploited.

\section{Acknowledgement}

I wish to express my deep appreciation for the ideas and efforts of the many renowned scientists and scholars put together in this review.

\section{References}

1. Abu, S., Anyaibe, S. and Headings, V. (1981). Chromatographic fractionation of antisickling Agents in Fagara zanthoxyloides. Acta Haematol. 66: 19-26. 


\section{Afr. J. Trad. CAM (2005) 2 (3): 282 - 301}

2. Addae-Mensah, I., Muriuki, G. and Sofowora, A. (1986). Structure and anti-hypertensive properties of Nitidine Chloride from Fagara species. Abstracts of short lectures and posters. $34^{\text {th }}$ Annual Congress on Medicinal Plant Research. Poster 79, pg. 58.

3. Adeoye, A. O. (1978). Phytochemical investigations for the establishment of Pharmacopoeial standards in Fagara species. M. Phil Thesis University of Ife, Ile-Ife, pages 1-142.

4. Adesanya, S.A (1980). The Biological standardization of the root of some Zanthoxylum species (Fagara spp) for antisickling activity. M.Phil Thesis, University of Ife, Ile-Ife, pages1-183.

5. Adesina, S.K. (1986). Further novel constituents of Zanthoxylum zanthoxyloides root and pericarp. J. Nat. Prod. 69: 715-716.

6. Adesina, S.K. (1989). Three New Amides from Zanthoxylum rubescen.s Planta Medica 55: 324-326.

7. Adesina, S.K. and C.O. Adewunmi (1985). Molluscicides from the root of Clausena anisata. Fitoterapia 56: 289-291.

8. Adesina S.K. and J. Reisch (1989). Amides from Zanthoxylum rubescens Phytochemistry 28 (3): 839-842.

9. Adesina, S.K., T.A. Olugbade, D.D. Akinwusi and D. Bergenthal (1997a). Extractives from Zanthoxylum lemairie root and stem. Pharmazie 52: 720-724.

10. Adesina, S.K., T.A. Olugbade, D.D. Akinwusi and D.J. Willert (1997b). New Amides from Zanthoxylum lemairie pericarps, Planta Med. 63: 286-287.

11. Arthur, H. R., W. H. Hui and Y. L. Ng (1958). Chem. Ind. (London), 1514; J. Chem. Soc. 1840 (1959).

12. Bowden, K. and. Ross, W. J. (1963). The local anaethetic in Fagara zanthoxyloides. J. Chem. Soc. 3503-3505.

13. Chaaib, F., E. F. Queiroz, K. Ndjoko, D. Diallo and Hostettmann, K.(2003). Antifungal and antioxidant compounds from the root bark of Fagara zanthoxyloides Planta Med. 69(4): 316-20 (2003).

14. Dalziel, J. M. (1937) (reprinted 1955). The useful plants of West Tropical Africa. Crown Agents for Overseas Governments and Administration, London.

15. Ekong, D.E., J.I. Okogun, V.U. Enyhenihi, B. Balogh-Nair, K. Nakanishi, and C. Natta (1975). New anti-sickling agent, 3,4-dihydro-2,2-dimethyl-2H-1-benzopyran-6-butyric acid. Nature 258 (5537), 743-746.

16. Elujoba, A.A. and Sofowora, E. A. (1977). Detection and estimation of total acid in the antisickling fraction of Fagara species. Planta Medica 34: 54-59.

17. Elujoba, A.A. and L. Nagels (1985): Chromatographic isolation and estimation of Zanthoxylum species. Journal of Pharm. And Biomed. Analysis 3(5): 447-451.

18. El-Said, F., S. O. Fadulu, J.O. Kuye and. Sofowora, E.A (1971). Native cures in Nigeria : II The antimicrobial properties of the buffered extracts of chewing sticks. Lloydia 34: 172-174.

19. Eshiett I.T. and Taylor, D.A.H. (1966). Extractives from Fagara zanthoxyloides Lam. Chem. Commun. 14: 476-8. 
Afr. J. Trad. CAM (2005) 2 (3): 282 - 301

20. (1968). The isolation and structure elucidation of some derivatives of dimethylallyl coumarin, chromone, quinoline and phenol from Fagara Species and from Cadrelopsis grevei. J. Chem. Soc. (C) 481-484

21. Fish, F. and P.G. Waterman (1971). A note on the chloroform-soluble alkaloids of Fagara macrophylla, J. Pharm. Pharmac. 23, 67-68.

22. Fish, F. and P.G. Waterman (1973): Chemosytematics in the Rutaceae II. The chemosystematics of the Zanthoxylum/Fagara complex. Taxon (2/3, 177-203.)

23. Gerzon, K. and Svoboda, G.H. (1983). Acridone Alkaloids: Experimental antitumour activity of acronycine in "The Alkaloids, Chemistry and Pharmacology" (Arnold Brossi Ed.) Publisher? Vol. 21, 1-28.

24. Gregor, H. (1984). Alkamides: Structural Relationships, Distribution and Biological Activity. Planta Medica 366-375.

25. Gupta, N.B., R. Hath, N. Srivastava, K. Shanker, K. Kishor and K.P. Bhargava (1980). Anti-inflammatory and anti-pyretic activities of $\beta$-sitosterol. Planta Medica 39:157-163.

26. Hallen, H.M., F. B. Lafoge, and. Sullivan, W. N (1942). J. Econ. Entomol 35: 247, -ibid - J. Org. Chem.. 7: 183 (1942).

27. Honig, G.R.., N.R. Farnsworth, C. Ferenc, L.M. Vida (1975). Evaluation of Fagara zanthoxyloides Root. Extract in Sickle Cell Anaemia Blood in vitro. Lloydia, 38: 387390.

28. Ichikawa, K., T. Kinoshita, S. Nishibe and U. Sankawa (1986): $\mathrm{The}^{2{ }^{2+}}$ antagonist activity of Lignans. Chem. Pharm. Bull. 34: 3514-3517.

29. Isaacs-Sodeye, W. A. (1973). Preliminary clinical evaluation of crude extracts of Fagara zanthoxyloides. Proceedings of the Symposium, Fagara and the red blood cell, University of Ife Press, Nigeria pp. 88-90.

30. Isaacs-Sodeye, W.A., E.A. Sofowora, A.O. Williams, V.O. Marquis, A.A. Adekunle and C.O. Anderson (1975): Extract of Fagara zanthoxyloides root in Sickle Cell Anaemia. Acta Haematol. 53: 158-164.

31. Ishii, H., T. Ishikawa, S-T. Lu and I-S, Chem (1976). Arnotianamide and isoarnottianamide, The structural establishment due to chemical conversion from the known Benzo[C]phenanthridine alkaloids by the novel Baeyer-Villiger-like oxidation of an immonium group. Tett. Letters 15 pp 1203-1206.

32. Jamwal, K.S.,M.L. Sharma, N. Chandhoke and B.J. Ray Chatak (1972). Indian J. Med. Research 60: 763.

33. Jacobson, M. (1954). Constituents of Heliopsis Species III, cis trans Isomerism in Affinin. J. Amer. Chem. Soc. 76: 4606-4608.

34. Krane, B.D., M. Fagbule, M. Shamma and B. Gozler (1984). The Benzophenanthridine Alkaloids, J. of Nat. Prod. 47: 1-43.

35. Kubo, I., T. Matsumoto, J.A. Klockie and T. Kamikawa (1984): Experientia 40, 340.

36. Kubo, I., J.A. Klockie, T. Natsumoto, T. Kamikawa (1984). Insecticidal and molluscicidal activities of isobutylamides isolated from Fagara macrophylla and their synthetic analogues. ACS Symposium Series (1984), 255, 163-17 CA: 16547z.

37. Lau-Cam, C.A., I. Chu-fong (1972). J. Pharm. Sci. 61: 1303. 
Afr. J. Trad. CAM (2005) 2 (3): 282 - 301

38. Mabry, T.J. and A. Ulubelen (1980). Chemistry and utilization of phenylpropanoids including flavonoids, coumarins and lignans J. Agric Food Chem. 28: 188-196.

39. MacRae W.D. and G.H. Neil Towers (1984). Biological activities of Lignans. Phytochemistry 23 (6): 1207-1220.

40. Massnaet, G.M., E. Pando, F. Rodriguez-Luis, E. Zubia (1989): Lignans, a Review, Fitoterapia LX, (1), 3-35.

41. Messmer W.M., M.Tin-Wa, H.H.S. Fong, C. Bevelle, N.R. Farnsworth, D. J. Abraham and J. Trojanek (1972). Fagaronine, a new tumour inhibitor isolated from Fagara zanthoxyloides Lam (Rutaceae). J. Pharm. Sci. 61: 1858-1859.

42. Mester, I. (1983). Structural Diversity and Distribution of Alkaloids in the Rutales, in, "Chemistry and Chemical Taxonomy of the Rutales: (P.G. Waterman and M.F. Grundon Eds.) Academic Press London, and references cited, pg. 31-96.

43. Mizutani, K., Y. Fukunuga, O. Tanaka, N. Takasugi, Y. Saruwatari, T. Fuwa, T. Yamachi, J. Wang. M. Jia, F. Li and Y. Ling, (1988): Amides from Juajiao, Pericarps of Zanthoxylum bungeanum Maxim. Chem. Pharm. Bull. 36, 2363-2365.

44. Odebiyi, O.O. and Sofowora, E. A. (1973). Antimicribial alkaloids from a Nigerian chewing stick (Fagara zanthoxyloides). Planta Med. 36: 204-207.

45. Ojewole, J.A.O. and S.K. Adesina (1983). Mechanism of the Hypotensive Effect of Scopoletin isolated from the fruit of Tetrapleura tetraptera Taub. Planta med. 49: 46-50.

46. Okogun, J. I., J.F. Ayafor, D.E.U. Ekong, and V.U. Enyenihi (1978): Extracts from the roots of the Nigerian and Cameroon varieties of Fagara zanthoxyloides. Nig. J. Sci. 12 (1 \&2): 589-603.

47. Olatunji, O.A. (1983). The Biology of Zanthoxylum Linn (Rutaceae) in Nigeria, in "Antiinfective agents of Higher Plants origin" (Essien, Adebanjo, Adewunmi, Odebiyi Eds.), Proceedings of the Fifth International Symposium on Medicinal Plants pp. 56-59.

48. Oliver-Bever, B. (1982). Medicinal Plants in Tropical West Africa, Plants acting on Cardiovascular system. J. Ethnopharmacol. 5: 1-17

49. Orafidiya, O.O., E.O. Ogunlana and R.N. Nasipuri (1992a) Studies on some physicochemical properties of the gum obtained from Zanthoxylum tessmannii (Engl.) Waterm. African J. Pharm.\& Pharma. Sci. 22: 69-79.

50. Orafidiya, O.O. (1989): Rheological Properties of aqueous solutions of the gummy exudates of Zanthoxylum tessmannii J. of Texture Studies 20: 285-299.

51. Orafidiya, O.O., E.O. Ogunlana and R.N. Nasipuri (1992b): Studies on some factors affecting the stability of emulsions prepared from Zanthoxylum gum. Gum from Zanthoxylum tessmannii (Engl.) Waterm. African J. Pharm. Sci. 22(3): 154-165.

52. Oriowo, M.A. (1982). Anti-Inflammatory Activity of Piperonyl-4-Acrylic Isobutyl Amide, an Extractive from Zanthoxylum zanthoxyloides. Planta Medica 44: 54-58.

53. Osoba, O.A., S.A. Adesanya, M.A. Durosimi (1989): Effecfs of Zanthoxylum zanthoxyloides and some substituted benzoic acids on glucose-6-phosphatte and 6phosphogluconate dehydrogenases in HBSS red blood cells. J. Ethnopharmacol. 27 (1-2): 177-183. 


\section{Afr. J. Trad. CAM (2005) 2 (3): 282 - 301}

54. Ouattara, B., L. Angenot, P. Guissou, P. Fondu, J. Dubois, M. Frederich, O. Jansen, J.C. van Heugen, J.N. Wauters and M. Tits (2004). LC/MS/NMR analysis of isomeric divanilloylquinic acids from the root bark of Fagara zanthoxyloides Lam. Phytochemistry 65 (8): 1145-1151.

55. Paris, R. and H. Moyse-Mignon (1951). Title? Ann Pharm. Fr. 479-493Principe, P. (1989). in "Economic and Medicinal Research. Vol.3 (Wagner, H. Hikino, H. and Farnsworth, N.R. Eds) Academic Press, London pp.1-17

56. Pousset, J.L (1988). Medicinal Plants Used As Source of Raw Material for the Pharmaceutical Industry, Problems and Prospects in, "Drug Production from Natural Products", Adesina S.K. (Ed.) Proceedings of the Seventh International Symposium, DRPU, OAU, Ife. pp.37-41.

57. Principe, P. (1989). In: Economic and Medicinal Research. Vol. 3 (Wagner, H., Hikino, H. and Farnsworth, N. R. Eds.) Academic Press, London pp. 1-17.

58. Reisch, J., S.K. Adesina and D. Bergenthal (1985). Constituents of Zanthoxylum leprieurii fruit pericarps, Die Pharmazie 4: 811-812.

59. Reisch, J., D. Bergenthal, S.K. Adesina, D. A. Akinwusi and A.O. Olatunji (1986). Constituents of Fagara macrophylla and Zanthoxylum tessmannii pericaps.J. Nat. Prod. 49: 1169-1171.

60. Simanek, V. (1985). Benzophenanthridine alkaloids in "The Alkaloids, Chemistry and Pharmacology” (Arnold Brossi, Ed.) Academic Press, London Vol. 26: 186-240.

61. Vaquette, J., A. Cavi et Waterman, P.G. (1978). Alcaloides des ecorces de racines et de tiges de Zanthoxylum bouetense (Pierre ex Letouzey) Waterm. Plantes medicinales et phytotherapie, Tome xii (3), pg. 235-239.

62. Wall, M.E., M.C. Wani and Taylor, H. (1987). Plant antitumour agents. 27. Isolation, structure and structure activity relationships of alkaloids from Fagara macrophylla. J. Nat. Prod. 50 (6): 1095-1099.

63. Waterman, P. G. (1986). A Phytochemist in the African Rain Forest. Phytochemistry 25 (1): 3-17.

64. Weenen, H.M., H.H. Nkunya, D.H. Bray, L.B. Mwasumbi, L.S. Kinabo, V.A.E.B. Kilimali, J.B.P.A. Wijnberg (1990). Antimalarial compounds containing an alpha Beta unsaturated carbonyl moiety from Tanzanian medicinal plants. Planta Medica 56 (4): 371-374.

65. Yasuda, I., K. Takeya and H. Itokawa (1981). Two new pungent principles isolated from the pericarps of Zanthoxylum ailanthoides Chem. Pharm. Bull. 29 (6): 1791-1793.

66. Vickery, H.B., E.M. Nelson and Almquist Elrehjem, H. J. (1950): Science 112: 628.

67. Sofowora E.A. and W.A. Isaac (1971). Reversal of sickling and crenation in erythrocytes by the root extract of Fagara zanthoxyloides Lloydia 34: 383-385.

68. Sofowora, E.A. (1974): Recent Developments in Research into the Antisickling Properties kof Fagara zanthoxyloides (Orin Ata). The J. Pharm. (Nigeria) 5: 8-14.

69. Sofowora, E.A., W.A. Isaac-Sodeye and L.O. Ogunkoya (1975): Isolation and characterization of an antisckling agent from Fagara zanthoxyloides Root. Lloydia 38: 169-174.

70. The World Sickle Cell Foundation Inc. (1990). 101B Camag Plaza, 4669 South-West Freeway Houston, Texas 77027.. 